Review

\title{
Drawing a Line: Grasses and Boundaries
}

\author{
Annis E Richardson ${ }^{1}$ and Sarah Hake ${ }^{1,2, *}$ \\ 1 Plant and Microbial Biology, University of California, Berkeley, CA 94720, USA; \\ annisrichardson@berkeley.edu \\ 2 USDA Plant Gene Expression Center, 800 Buchanan Street, Albany, CA 94710, USA \\ * Correspondence: hake@berkeley.edu; Tel.: +01-510-559-5907
}

Received: 3 November 2018; Accepted: 18 December 2018; Published: 25 December 2018

check for updates

\begin{abstract}
Delineation between distinct populations of cells is essential for organ development. Boundary formation is necessary for the maintenance of pluripotent meristematic cells in the shoot apical meristem (SAM) and differentiation of developing organs. Boundaries form between the meristem and organs, as well as between organs and within organs. Much of the research into the boundary gene regulatory network (GRN) has been carried out in the eudicot model Arabidopsis thaliana. This work has identified a dynamic network of hormone and gene interactions. Comparisons with other eudicot models, like tomato and pea, have shown key conserved nodes in the GRN and species-specific alterations, including the recruitment of the boundary GRN in leaf margin development. How boundaries are defined in monocots, and in particular the grass family which contains many of the world's staple food crops, is not clear. In this study, we review knowledge of the grass boundary GRN during vegetative development. We particularly focus on the development of a grass-specific within-organ boundary, the ligule, which directly impacts leaf architecture. We also consider how genome engineering and the use of natural diversity could be leveraged to influence key agronomic traits relative to leaf and plant architecture in the future, which is guided by knowledge of boundary GRNs.
\end{abstract}

Keywords: grass; ligule; organogenesis; boundaries

\section{Organogenesis}

Organogenesis is the self-organizing process in which complex tissues arise from pluripotent progenitors and is common to all multicellular organisms. In plants, the process of organogenesis extends beyond embryogenesis, which enables them to continually produce organs. All aerial organs arise as relatively simple-shaped primordium on the periphery of the shoot apical meristem (SAM), which contains the pluripotent stem cells. The first molecular marker of organogenesis is the downregulation of class 1 KNOTTED-LIKE HOMEOBOX (KNOX) genes in the peripheral zone of the SAM [1-3]. This earliest stage of primordium growth is referred to as the P0, with the plastochron stage $(\mathrm{P})$ as the time between successive primordium initiations.

The spacing of organ primordia around a SAM (the phyllotaxy) is self-organizing and highly robust. Phyllotaxy is determined by the distribution of the phytohormone auxin, which is influenced by the directional export of auxin by the PIN-FORMED transporters (PIN). This process is a self-organizing feedback loop, and the spacing between each primordium is predicted to be influenced by the size of the region of auxin depletion around the older primordium [4-10]. The formation of PIN1 convergence points in the SAM of the model eudicot plant Arabidopsis thaliana is essential for organ initiation [11-15]. This PIN1 convergence point leads to the formation of an auxin maximum and the subsequent downregulation of KNOX genes, which allows differentiation and outgrowth of organ primordia. 


\section{Boundaries and Plant Development}

A fundamental step in organogenesis of multicellular organisms is the delineation of distinct populations of cells by forming boundaries. Boundary formation is essential for the function of the mature organ since it allows correct patterning and the segregation of different activities. In the case of vegetative development in plants, the formation of a boundary between the SAM and the incipient primordia is essential for both maintenance of the stem cell population and the correct shape of the mature organ [16]. This meristem/organ boundary allows for the separation of the cells that will become determinate and form the organ, while those that retain an indeterminate state maintain the meristem.

Meristem/organ boundaries are characterized by low division and expansion rates, parallel oriented microtubules, and relatively stiff cell walls [17]. These features contrast with the high cell division and cell expansion rates, low cell wall stiffness, and perpendicular oriented microtubules in the primordium tissue. The difference between the tissue properties of boundaries and the primordium generates conflict within the tissue, which allows the physical bulging of the primordium from the surface of the meristem [18-20]. The distribution of differentially growing regions can then generate distinct shapes [21]. Therefore, in addition to roles in separation of functionally different tissues, boundaries also contribute to organ shape through differential growth patterning [22].

Boundaries also form within the organ itself, delineating different tissues. These within-organ boundaries can have central roles in the final organ shape. For example, the juxtaposition of the abaxial and adaxial tissues in the leaf are essential for lamina outgrowth [23-25]. Within-organ boundaries can also be elaborated, contributing to morphological diversity. For example, stipules form at the base of the petiole in eudicot leaves such as peas [26]. Boundary regions can also be elaborated in mutants in response to ectopic gene expression. For example, ectopic KNOTTED1 expression in the lemma/awn boundary in the barley Hooded mutant, results in the formation of a "hood" structure consisting of an ectopic floral meristem and triangular lateral outgrowths [27-31]. Similarly, ectopic KNAT1 expression leads to meristems forming in the boundary regions of the lobed leaf [32].

\subsection{The Boundary Gene Regulatory Network}

Most of our understanding in how meristem/organ boundaries are defined has come from genetic studies in Arabidopsis. Of particular importance are mutants that have a fused organ phenotype, including cup-shaped-cotyledon $1 / 2 / 3$ (cuc), growth regulating factor (grf), and lateral organ boundary (lob) mutants [16,33-36], which highlighted key boundary genes. This body of work has shown that boundary specification requires a complex network of transcription factors, miRNAs, and hormone interactions summarized in Figure 1. Central players include the NAC domain transcription factors, NO APICAL MERISTEM (NAM, or AtCUC1, and AtCUC3), which are regulated by miR164, and are part of a feedback network with the KNOX gene, SHOOTMERISTEMLESS (STM) [33-35,37-46]. The CUC transcription factors also directly regulate the expression of other boundary genes, such as LIGHT-DEPENDENT SHORT HYPOCOTYLS 3 and 4 (LSH3 and 4), which are proposed to suppress organ differentiation [37]. Downstream of the CUC genes, GRFs are also expressed in the boundary, which play a role in the suppression of cell division and expansion [34].

Low growth rates in the boundary are also influenced by the spatial distribution of growth promoting hormones like auxin and brassinosteroids (BR) [47]. Both auxin and BR maintain higher levels in the meristem and developing primordia, and low levels in the boundary. Low auxin levels in the boundary are influenced by JAGGED LATERAL ORGANS (JLO) [39]. High BR in the primordium feeds back to regulate the spatial expression of the CUC genes, which limits them to the boundary domain. This inhibition is through BR promotion of BRASSINAZOLE-RESISTANT 1 (BZR1) expression, which inhibits $C U C$ expression. Low BR levels in the boundary are influenced by the expression of PHYB ACTIVATION TAGGED SUPPRESSOR1 (BAS1), which is a BR inactivating enzyme [35]. The expression of $B A S 1$ is regulated directly by the boundary gene $L O B 1$, and $B R$ can influence $L O B$ expression forming a reinforcing feedback loop [35], restricting low BR to the boundary domain. 


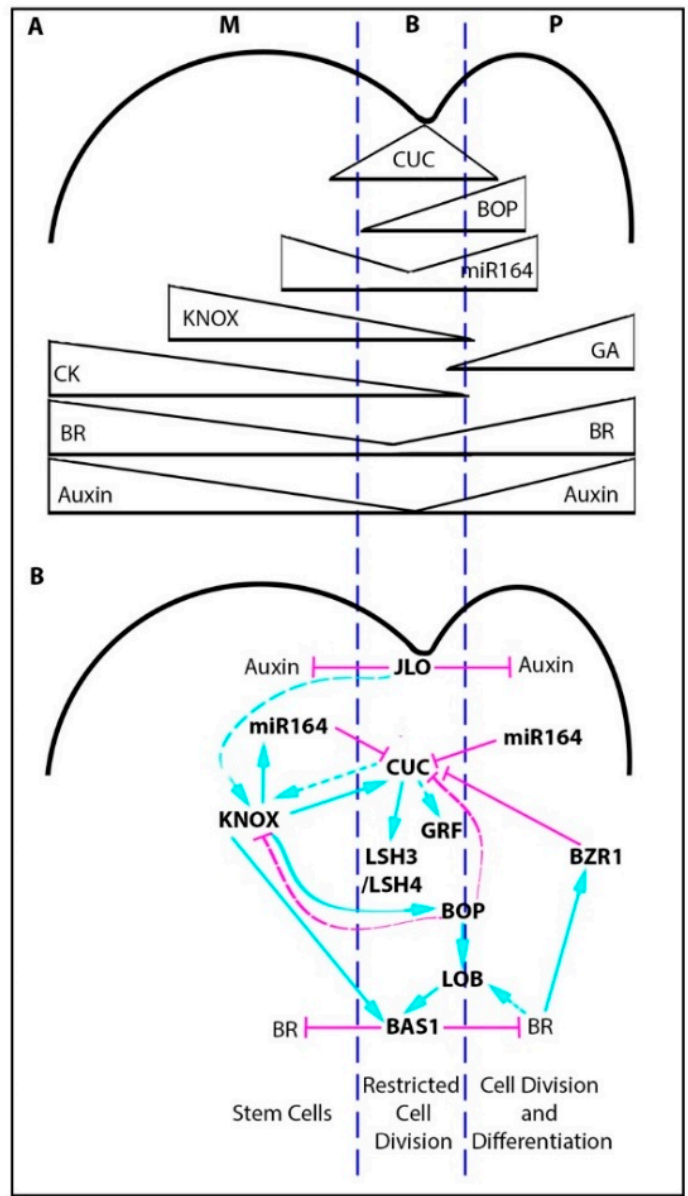

Figure 1. Regulation of meristem-organ boundaries in Arabidopsis. (A) Gradients of a selection of gene expression patterns and hormones across the meristem/organ boundary. (B) A summary of the gene regulatory network involved in meristem/organ boundary specification. Blue arrows indicate positive regulation while magenta lines indicate negative regulation. Solid lines represent direct regulation, dashed lines, indirect regulation. The dark blue lines delineate the meristem (M), boundary (B), and primordium (P) regions.

The boundary region is further refined through the activity of the ankyrin repeat proteins BLADE-ON-PETIOLE 1 and 2 (BOP1 and 2), which are localized to the base of the developing primordium. BOP activity results in the repression of CUC gene expression in the base of the primordium, and promotes the expression of $L O B$ transcription factors [48,49].

Overall, these feedback networks maintain a clear boundary domain delineating the two distinct populations of cells (the meristem and the differentiating primordium) and spatially pattern distinct growth patterns.

\subsection{The Boundary Gene Regulatory Network and Leaf Margin Development}

The boundary gene regulatory network also has a role in the elaboration of leaf margin development, in particular, influencing serration and compound leaf development in eudicot systems including Arabidopsis, Cardamine hirsuta, tomato, and pea [50-55].

Despite the fact that many of the boundary components are shared between species, work in diverse eudicots has highlighted key differences in the network when it has been co-opted for margin development. For example, in tomato the KNOX gene TKn1 is sufficient to initiate compound leaf formation. However, in peas KNOX genes do not have a role in compound leaf development and the pea ortholog of LEAFY (UNI) is sufficient to initiate compound leaf development [56,57]. LFY/UNI in 
peas allow formation of compound leaves by promoting indeterminacy in the margin, while LFY in inflorescences cause determinate growth in flowers. In tomatoes, gibberellic acid (GA) inhibits leaf complexity but, in peas, GA promotes leaf complexity [50]. This co-option of the boundary network in margin elaboration and the variations between eudicot species illustrates that different plant species can use the same regulators to induce opposite effects. Different eudicots also use specific factors to modulate leaf margin development. For example, the homeodomain protein RCO functions to inhibit growth in the boundary of developing leaflets in Cardamine hirsuta. RCO is specific to the core Brassicacae but was lost in Arabidopsis [58].

Given the profound effect that boundary specification can have on leaf shape and plant productivity, translating this research into crop species is vital. This translation is especially important when considering future aims of developing accurate computational models of crop growth and development to help predict the effects of a changing climate on crop productivity. In this paper, we review the current understanding of boundary specification during vegetative development, and the effects on leaf morphology in grass crops in comparison with eudicot models (Table 1).

Table 1. Glossary of studied related genes in Arabidopsis, maize, and barley mentioned in the review.

\begin{tabular}{llll}
\hline Arabidopsis & Maize & Barley & Description \\
\hline $\begin{array}{l}\text { SHOOTMERISTEMLESS } \\
\text { (STM) }\end{array}$ & KNOTTED1 (KN1) & $\begin{array}{l}\text { BARLEY KNOTTED 3 } \\
\text { (BKn3) }\end{array}$ & $\begin{array}{l}\text { KNOX transcription } \\
\text { factor }\end{array}$ \\
\hline $\begin{array}{l}\text { CUP-SHAPED COTYLEDON } \\
1,2,3 \text { (CUC1, 2, 3) }\end{array}$ & $\begin{array}{l}\text { NO APICAL MERISTEM 1 and } \\
\text { 2 (NAM 1,2), CUC3 }\end{array}$ & $\begin{array}{l}\text { NAC domain } \\
\text { transcription factor }\end{array}$ \\
\hline \multirow{2}{*}{ BLADE ON PETIOLE 1 (BOP) } & $\begin{array}{l}\text { TASSELS REPLACE UPPER } \\
\text { EARS 1 (TRU1) and TRU1-like }\end{array}$ & UNICULME4 (CUL4) & $\begin{array}{l}\text { Ankyrin repeat domain } \\
\text { protein }\end{array}$ \\
\hline miR164 a/b/c & miR164 a/b/c/d/e/f/g/h & microRNA \\
\hline PIN-FORMED 1 (PIN1) & $\begin{array}{l}\text { PINFORMED 1a and 1b (PIN1a, } \\
\text { PIN1b) }\end{array}$ & Auxin transporter \\
\hline not present in Arabidopsis & SISTER OF PIN1 (SoPIN1) & Auxin transporter \\
\hline
\end{tabular}

\section{Vegetative Organogenesis in Grass Crops}

Most of the major food crops, including wheat, rice and maize, are members of the grass family (Poaceae) and are part of the monophyletic clade called the monocots. The monocots diverged from eudicot species 150 mya [59]. Monocots have distinct leaf shapes, generally sharing an ensheathing leaf base and parallel venation. These shape differences between monocots and eudicots are clear from the earliest stages of organogenesis (Figure 2A-H).

Unlike eudicot models in which the P0 is a point on the SAM that grows out to form a peg-like outgrowth (Figure $2 \mathrm{~F}-\mathrm{G}$ ), in the grasses, the leaf $\mathrm{P0}$ encircles the SAM (Figure 2B-C), and is referred to as the disc of insertion $[60,61]$. This disc of insertion forms the ensheathing leaf base. Each successive leaf base encircles both the meristem and all younger leaves, forming whorls containing a single leaf (Figure 2C). Like eudicot models, auxin accumulation followed by the downregulation of class 1 KNOX genes [1] is central to organ initiation in the grasses (Figure 2C). When auxin signaling is disrupted, as is the case when maize SAMs are treated with the auxin inhibitor NPA (N-1-naphthylphthalamic acid), organ initiation and KNOX downregulation is halted [62]. Auxin signaling is, therefore, central to recruitment of cells into the primordia in grasses, which is similar to eudicots.

Auxin maxima are formed by convergence points of PIN1 in Arabidopsis meristems. In contrast to Arabidopsis, the grass model, Brachypodium distachyon, has two PIN1 orthologues known as PIN1a and PIN1b, and a sister clade to PIN1, SISTER OF PIN1 (SoPIN1), with each showing sub-functionalization. This is independent of transcriptional control. PIN1a and PIN1b accumulate in the vasculature and the pin1a/pin1b double mutant has short internodes. SoPIN1 forms convergence points in the inflorescence meristem and the mutant has organ initiation defects similar to the Arabidopsis pin1 mutant $[63,64]$. The SoPIN1 clade is not unique to the grasses and is found in eudicots, including Medicago truncatula and tomato, but was lost in the Brassicaceae family. Mutants in the SoPIN1 clade in 
Medicago and tomato (entire2) show pleiotropic effects including defects in leaf development $[65,66]$, which suggests that SoPIN1 could have a role in grass leaf development even though it was not reported for Brachypodium [63].

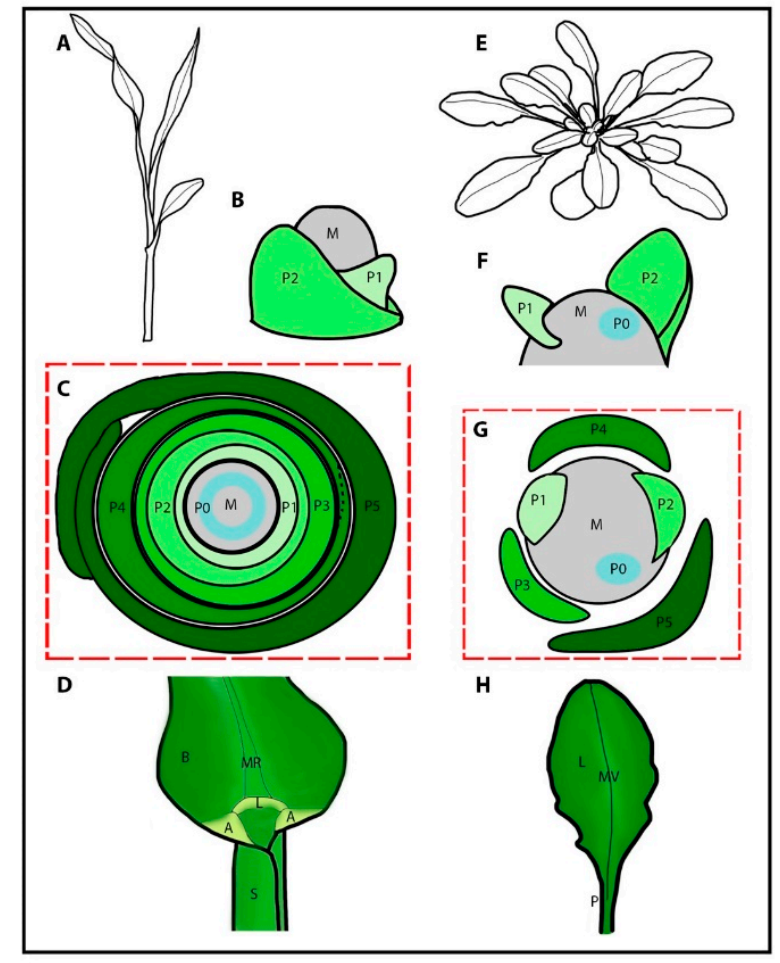

Figure 2. Grasses have distinct leaf and primordium shapes. A comparison of the morphology of the grasses versus Arabidopsis during vegetative development. (A) A cartoon of a grass seedling. (B) A cartoon representation of a grass vegetative meristem (M) with the first and second leaf primordia shown (P1 and P2) encircling the meristem. (C) A cartoon of a transverse cross section through a grass seedling, showing how each successive leaf (P1-P5) encircles the meristem and the younger leaves. The $\mathrm{P} 0$ is the region of $K N O X$ gene expression down-regulation, which forms a ring. The sheath margin boundaries are not defined until P4 (dotted line) after which the margins are separate (P5). (D) A cartoon of the blade/sheath boundary in a mature grass leaf, depicting the blade (B), midrib (MR), ligule (L), auricles (A), and the sheath (S). (E) A cartoon of an Arabidopsis plant during vegetative growth. (F) A cartoon representation of an Arabidopsis vegetative meristem (M) with the first and second leaf primordia shown (P1 and P2), which do not encircle the meristem. (G) A cartoon of a transverse cross section through an Arabidopsis seedling, showing each successive leaf (P1-P5). (H) A cartoon of a mature Arabidopsis leaf, depicting the lamina (L), midvein (MV), and the petiole (P).

Once the disc of insertion has been specified, the ring-shaped P1 primordium (Figure 2B), goes on to develop into a grass leaf with a modular structure (Figure 2A). The wrapped lower leaf region known as the sheath provides structural support. The middle hinge region regulates a leaf angle and develops two distinct structures including the ligule, which is a fringe of tissue proposed to act as a sliding gasket, and two triangular auricle regions at the leaf margin, which influence the leaf angle (Figure 2D). The upper region known as the blade bends away from the plant and intercepts light. The interaction between these three regions influences plant height and the leaf angle, which has significant impacts on plant productivity [67-75]. These traits are of high agronomic importance since they can directly affect the yield of an individual plant, and the yield of an entire field when planting density is taken into consideration.

Clonal sector analyses of grass leaf development have shown that during the earliest stages of leaf primordium development from P0 to P3, only the blade forms. Then from P3-P4, the sheath 
margins arise from an overlapping region in the disc of insertion [61,76] and the ligule/auricle region begins to differentiate [77]. Therefore, during the earliest stages of grass leaf development, three different boundaries need to be specified for correct leaf shape; the ring-shaped meristem/organ boundaries (which go on to become the boundaries between the leaf whorls), the intra-whorl boundaries (the boundary between the sheath margins) and a within-organ boundary (the boundary between the sheath and blade where the ligule and auricle form) (Figure 2C-D).

\section{Boundary Specification in Grass Crops}

\subsection{Meristem/Organ Boundaries in the Grasses}

Meristem/organ boundaries in the grasses form an encircling ring (Figure 2B,C). Without correct specification of this boundary, delineation between the stem cells (the SAM) and the differentiating primordium cells fails to occur. A lack of separation between differentiating and pluripotent cells results in the termination of the meristem, as observed in mutants such as the cupuliformis in Antirrhinum, cuc1/2/3 in Arabidopsis, and nam in Petunia, which all have mutations in the NAC domain transcription factor family NAM/CUC3 [16,36,78,79]. These classic meristem-organ boundary mutants also develop fused leaves and floral organs due to the lack of KNOX gene downregulation in the organ boundaries. Thus, highlighting the role of boundaries in maintaining the separation between successive whorls of organs as well as maintaining the meristem. Conversely, meristem-like activity can spread into the leaf if the boundary is not maintained. In the case of the blade-on-petiole (bop1) mutant in Arabidopsis, KNOX gene activity, which is indicative of a meristem-like identity, spreads into the leaf base resulting in the formation of ectopic leaf tissue [80].

Grass genomes have representatives of the core genetic elements in the Arabidopsis meristem-organ boundary regulatory network (Table 2). For example, the NAM and CUC3 genes, and the core miRNA164-NAM module likely predates the monocot/eudicot split [81-83]. Rice has one representative of NAM (Os06g0267500) and CUC3 (Os08g0511200), but maize, like Arabidopsis, has two NAM genes (GRMZM2G139700 and GRMZM2G393433) and one CUC3 (GRMZM2G430522), which illustrates gene duplication of the NAM family outside of the Brassicas [51]. The expression pattern of ZmCUC3 in maize lateral organs and the SAM mirrors that in eudicots, although the patterns of ZmCUC3 and the ZmNAM1/2 genes during embryo development differ [81]. Similarly, maize has a recent duplication of the AtBOP1/2 genes called TASSELS REPLACE UPPER EARS 1 (ZmTRU1, GRMZM2G039867) and TRU1-like (ZmTRL1, GRMZM2G060723), whereas rice has only a single gene, OsBOP (Os01g72020) [84].

Unlike the NAM/CUC3 and BOP genes, some of the gene families implicated in meristem-organ boundary specification are enlarged in the grasses. For example, where there are three members of the miR164 family in Arabidopsis (miR164a,b,c), there are six reported in rice (miR164a,b,c,d,e,f) and eight in maize (miR164a,b,c,d,e,f,g,h) [85]. In Arabidopsis, the three miR164 family members are functionally redundant but exhibit expression domain differences suggesting some sub-functionalization [86]. miR164b has a role in regulating NAC transcription factor expression during lateral root formation in maize, which indicates a function in patterning lateral outgrowths [87]. The roles of other miRNA164 family members in grasses are yet to be elucidated, especially considering the large size of the NAC transcription family (for example, rice has 149 members) [88]. This expansion of gene families may provide the opportunity for sub-functionalization of key boundary regulatory genes in the grasses.

Forward genetic screens in grasses have identified mutants with tube and fused leaves, which could be indicative of mutations in meristem/organ boundary regulation genes. So far, these mutants with fused leaf phenotypes such as rice onion-1, 2, and 3, maize adherant1, and fused leaves1 (fdl1), have defects in epidermal wax deposition and are not associated with any of the canonical boundary regulatory genes, such as NAM or CUC3 genes [89-94]. The lack of nam/cuc3 family mutants could suggest functional redundancy in the grass family, or that the mutations are embryo lethal, which implies that the leaf phenotype cannot be observed. 
Table 2. Glossary of grass gene names. Where appropriate, the activity relevant to this review is highlighted.

\begin{tabular}{|c|c|c|}
\hline Gene Name & Species & Description \\
\hline KNOTTED 1 (KN1) & Maize & KNOX Transcription Factor, meristem identity \\
\hline $\begin{array}{l}\text { NO APICAL MERISTEM } 1 \text { and } 2 \text { (NAM } \\
1,2) \text {, CUC3 }\end{array}$ & Maize & $\begin{array}{l}\text { NAC domain, transcription factor, expressed in } \\
\text { boundary domains }\end{array}$ \\
\hline $\begin{array}{l}\text { TASSELS REPLACE UPPER EARS } 1 \\
\text { (TRU1) and TRU1-like }\end{array}$ & Maize & $\begin{array}{l}\text { Ankyrin repeat domain protein expressed in the } \\
\text { sheath and in axillary meristems. }\end{array}$ \\
\hline PINFORMED 1a and 1b (PIN1a, PIN1b) & Maize & Auxin transporter \\
\hline SISTER OF PIN1 (SoPIN1) & Maize & Auxin transporter \\
\hline RAMOSA 2 (RA2) & Maize & $\begin{array}{l}\text { Lateral organ boundary domain transcription factor, } \\
\text { involved in axillary meristem development. }\end{array}$ \\
\hline SPARSE INFLORESENCE 1 (SPI1) & Maize & YUCCA gene, auxin biosynthesis. \\
\hline NARROWSHEATH 1 and 2 & Maize & WOX genes, involved in leaf development \\
\hline LIGULELESS1 (LG1) & Maize & $\begin{array}{l}\text { Squamosa Binding Protein transcription factor, } \\
\text { involved in ligule development. }\end{array}$ \\
\hline LIGULELESS2 (LG2) & Maize & $\begin{array}{l}\text { BZIP/DOG domain transcription factor, involved in } \\
\text { ligule development. }\end{array}$ \\
\hline LIGULELESS NARROW (LGN) & Maize & $\begin{array}{l}\text { Serine-threonine kinase, involved in ligule } \\
\text { development. }\end{array}$ \\
\hline LIGULELESS3 (LG3) & Maize & $\begin{array}{l}\text { KNOX transcription factor, ectopic expression of LG3 } \\
\text { induces ectopic blade/sheath boundaries. }\end{array}$ \\
\hline LIGULELESS4 (LG4) & Maize & $\begin{array}{l}\text { KNOX transcription factor, ectopic expression of LG4 } \\
\text { induces ectopic blade/sheath boundaries. }\end{array}$ \\
\hline GNARLEY4 (GN4) & Maize & $\begin{array}{l}\text { KNOX transcription factor, ectopic expression of LG4 } \\
\text { induces ectopic blade/sheath boundaries }\end{array}$ \\
\hline WAVY AURICLES IN BLADE 1 (WAB1) & Maize & $\begin{array}{l}\text { TCP transcription factor, ectopic expression of WAB1 } \\
\text { induces ectopic blade/sheath boundaries }\end{array}$ \\
\hline $\begin{array}{l}\text { BEL1-like homeodomain } 12 \text { and } 14 \\
\text { (BEL12/14) }\end{array}$ & Maize & $\begin{array}{l}\text { BEL1-like homeodomain transcription factors, } \\
\text { expressed in the developing ligule }\end{array}$ \\
\hline $\begin{array}{l}\text { BRASSINOSTEROID INSENSITIVE } 1 \\
\text { (BRI1) }\end{array}$ & Maize & $\begin{array}{l}\text { Brassinosteroid receptor, involved in auricle } \\
\text { development and leaf angle }\end{array}$ \\
\hline $\begin{array}{l}\text { BRASSINOSTEROID-DEFICIENT } \\
\text { DWARF1 (BRD1) }\end{array}$ & Maize & $\begin{array}{l}\text { Brassinosteroid C6-oxidase, involved in } \\
\text { brassino-steroid synthesis, expressed in the base of } \\
\text { leaves. Involved in ligule and auricle development. }\end{array}$ \\
\hline BETA-D-GULCOSIDASE 1 (GLU1) & Maize & Expressed in developing ligules \\
\hline UNICULME4 (CUL4) & Barley & $\begin{array}{l}\text { Ankyrin repeat domain protein, expressed in the } \\
\text { sheath and involved in ligule development }\end{array}$ \\
\hline ELIGULUM A (ELIA) & Barley & $\begin{array}{l}\text { RNase } \mathrm{H} \text { domain protein, involved in ligule } \\
\text { development }\end{array}$ \\
\hline
\end{tabular}

Although no nam or cuc3 mutants have been reported in the grasses, mutants in the orthologues of several boundary genes are known. Two orthologues of AtBOP1 are found in maize known as TRU1 and TRL1. The maize tru1 mutant does not have a leaf phenotype, although the protein accumulates in an interesting sheath pattern [84]. ZmTRL1 has no reported mutant phenotype. The two genes may be partially redundant with respect to vegetative organ boundary specification. In barley, the AtBOP1 orthologue HvCUL4, has a defect in leaf development, with the cul4 mutant showing a displacement of ligule/ auricle tissue [95]. This may mirror the displacement of distal identities within the proximal tissue observed in Arabidopsis. 
Arabidopsis lob mutants have fusions between cauline leaves and branches but normal vegetative organs. $L O B$ is expressed at the base of lateral organs and plays a role in negatively regulating BR signaling in boundaries [33,35]. Double and triple mutant analysis of the homologues of AtLOB show no additional phenotypes, but expression analysis highlights distinct expression patterns, suggesting sub-functionalization based on changes in the expression pattern rather than in a coding sequence [96]. In maize, the function of one homolog of $A t L O B$ has been examined so far, RAMOSA2 (RA2). RA2 regulates axillary meristem formation during inflorescence development. However, there are no reported organ fusion phenotypes in the ramosa 2 mutant, which contrasts with the AtLOB function [97].

The apparent conservation of boundary gene families suggests a common mechanism for meristem/organ boundary specification in eudicots and grasses, but the exact roles of the genes in grasses are yet to be understood. Some examples studied so far, such as $R A 2$, illustrate diversity in gene function.

\subsection{Intra-whorl Boundaries (the Boundary Between the Overlapping Margins of the Sheath) in the Grasses}

The sheath arises from an overlapping region in the disc of insertion during early P3/ late P4 development, requiring the formation of a new boundary between the two sheath margins (intra-whorl boundary) (Figure 2C, P4 dotted line). The delineation is shown clearly by the expression of adaxial and abaxial markers in the region of the incipient sheath margins [98]. Separation of sheath margins is dependent on auxin since the sheath remains fused and tube-like when plants are cultured in the presence of the auxin inhibitor NPA. In support of this dependency, expression of auxin biosynthesis genes such as SPARSE INFLORESCENCE 1 (SPI1, a YUCCA gene) is observed at the incipient sheath boundary. ZmNAM2 (also called $\mathrm{ZmCUC2}$ ) is also expressed in this region, which suggests the recapitulation of the meristem-organ boundary specification at this location and stage in grass leaf development [98].

What specifies or activates this intra-whorl boundary pathway forming the sheath margins is not clear. The narrowsheath $1 / 2$ double mutant in maize lacks this region, suggesting a role for NS1/2 in patterning or growth of this region [99]. Comparisons of monocots with fused sheaths, such as seen in some members of the sedges, could help elucidate this component in grass sheath development, highlighting factors involved in the evolution of the grass leaf.

\subsection{Within-Organ Boundaries (the Blade/Sheath Boundary and the Development of the Ligule and Auricle) in the Grasses}

The boundary between the grass leaf sheath and the blade develops characteristic structures; the ligule and the auricle; which directly influence the leaf angle, and can be used to define different species.

The first indication of the ligule during maize leaf development is an apparent increase in cell divisions in both a transverse and longitudinal direction in the adaxial epidermis to form the pre-ligule band [77]. Shortly thereafter, a reoriented accumulation of ZmPIN1a in the epidermis is observed, suggesting that, like organ initiation in the meristem periphery, auxin signaling is important in ligule formation and outgrowth [100]. Laser capture RNAseq of developing ligules found that ligule development involves the recapitulation of the meristem/organ boundary network within the developing leaf [101], highlighting roles for transcription factors such as ZmNAM2 in addition to auxin, giberellic acid (GA), cytokinin (CK), and brassinosteroid (BR) signaling. This RNAseq dataset suggests that, like eudicot leaf margin modification, the grasses have recruited a common boundary specification network in the development of a novel leaf morphology.

Mirroring the diversification observed in leaf margin development in eudicots, analysis of grass mutants with defects in the ligule/auricle boundary have identified species-specific components. The many blade/sheath boundary mutants in maize, barley, and rice highlight the role of different 
genes. Some appear to be specific to the outgrowth of the ligule, while others influence the specification of the blade/sheath boundary.

\subsubsection{Liguleless Mutants and the Patterning of the Ligule}

LIGULELESS1 and 2 (LG1 and LG2) are grass-specific transcription factors belonging to the squamosa binding transcription factor and BZIP/DOG domain transcription factor families, respectively. In maize, $\lg 1$ mutants retain a clear blade sheath boundary, but lack the ligule and auricle [102] (Figure 3). In rice and barley, lg1 mutants are more severe than in maize, completely lacking the ligule region in all leaves $[103,104]$. The milder phenotype of maize may be explained by duplicates of ZmLG1. LG1 is expressed in the pre-ligular band [101] and acts cell autonomously, which suggests that LG1 functions to specify the ligule [105]. $\lg 2$ mutants, in contrast, have a diffuse blade/sheath boundary and retain reduced auricles at the margins which are displaced vertically relative to each other (Figure 3). lg2 mutant phenotypes are yet to be described in other grasses. ZmLG2 has a broad expression pattern but a specific protein localization, and it is able to act non-cell autonomously. The phenotype of $\lg 2$ has led to the hypothesis that LG2 may have a role in defining the blade/sheath boundary itself $[105,106]$. Double mutant analysis in maize has suggested that both LG1 and LG2 act in the same pathway [105], with LG2 being expressed earlier than LG1 [100,106,107].

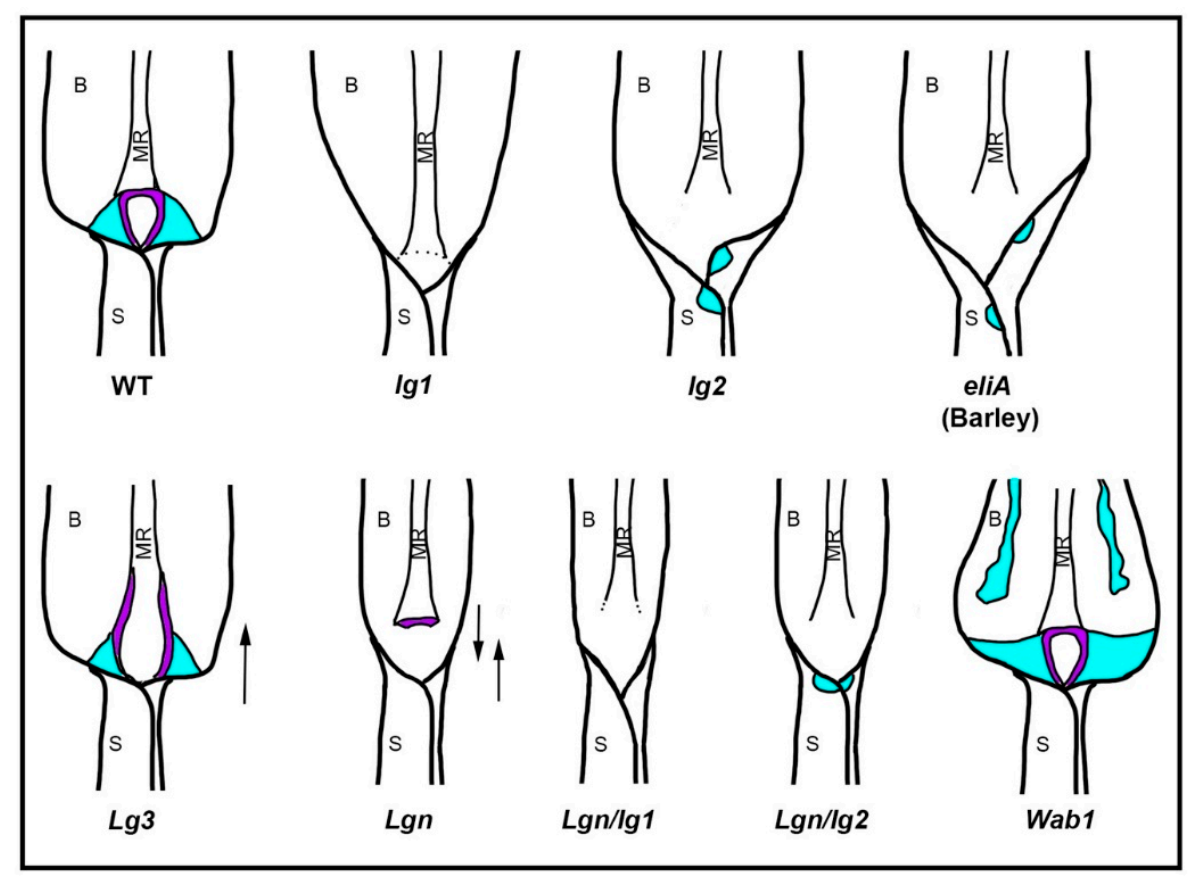

Figure 3. The morphology of the leaf blade/sheath boundary in reported ligule mutants. Cartoons depicting the typical morphology of the blade/sheath boundary in mature leaves of wild-type (WT), liguleless1 (lg1), liguleless2 (lg2), eligulumA (eliA, a barley mutant), Liguleless3 (Lg3), Liguleless narrow (Lgn), double Lgn/lg1, double Lgn/lg2, and Wavy Auricles in Blade (Wab1) plants. In each cartoon, the blade (B), midrib (MR), and sheath (S) are labelled. The ligule (purple) and the auricles (cyan) are also highlighted. Where the mutant leaf lacks a ligule, but retains a clear boundary between the blade and sheath, the boundary is indicated by a dotted line. The arrows indicate the direction of the displacement of the sheath tissue in the mutant.

RNAseq of $\lg 1$ mutants showed an enrichment of differentially expressed genes involved in auxin signaling, in addition to MYB and SBP transcription factors [101]. The directly bound and modulated targets of LG1 and LG2, however, are yet to be identified. Given data from other species, LG1 and LG2 may form heterodimers with other transcription factors. For example, in Arabidopsis, the BZIP DOG domain transcription factor PERIANTHIA (a member of the same clade of BZIP transcription factors 
as LG2 [108]) is involved in floral development, and interacts with BOP1 and 2 in yeast [49]. The barley orthologue of AtBOP2, UNICULME4 (HvCUL4) functions in axillary meristem development and in ligule specification [95]. These observations lead to the hypothesis that LG2 may interact with BOP homologues in the grasses to pattern the blade/sheath boundary.

In addition to homo-dimerization and hetero-dimerization, BZIP transcription factor activity has been shown to be post-translationally regulated via phosphorylation [109]. LIGULELESS NARROW (LGN) is a serine-threonine kinase that is non-functional in the dominant mutant, Lgn-R. Lgn-R mutants have a pleiotropic phenotype including narrower leaves, the loss of the ligule except at the midrib, and a diffuse blade/sheath boundary (Figure 3). This mutant has led to the hypothesis that a phosphorylation cascade propagates the ligule signal from the midrib to the margins of the leaf. A role for phosphorylation was also highlighted by network analysis where the authors proposed that a membrane associated kinase regulator (MPKR) could act with bHLH transcription factors to influence brassinosteroid (BR) signaling in the ligule [110]. Mutants in rice with reduced BR synthesis such as dwarf4-1, ebisu dwarf (d2), brassinosteroid-deficient dwarf 1 (brd1), or BR signaling, such as d61, have more upright leaves [111-114]. Similarly, RNAi knock-down of the BR signaling components, OsBAK1 in rice and ZmBRI1 in maize, have reduced BR signaling and more upright leaves with reduced auricles $[115,116]$. The maize $b r d 1$ mutant has reduced BR synthesis with defects in ligule and auricle development [117]. ZmBRD1 is expressed in the base of P3 leaves [101], which overlaps with the localization of TRU1 [84]. These results suggest that phosphorylation cascades and BR may be involved in mediolateral patterning of the blade/sheath boundary.

The barley liguleless mutant eligulum $A$ has a diffuse blade/sheath boundary (Figure 3 ) and carries a mutation in a gene that encodes a protein with an RNaseH domain but otherwise of unknown function [118]. In barley, ELIA is expressed in an overlapping domain with LG1. Although no eligulum mutant has yet been reported in maize, gene network analyses highlight a module expressed in the pre-ligule band that includes both maize homologues of ELIA [110]. These results suggest that ELIA may play an, as yet, unknown role in the blade/sheath boundary specification and ligule development across the grasses.

\subsubsection{Ectopic Induction of New Blade/Sheath Boundaries}

Several dominant maize mutants exhibit ectopic formation of new blade/sheath boundaries, suggesting an additional regulatory network involved in initiating blade/sheath boundary patterning. In support of this, the genes able to trigger ectopic blade/sheath boundaries form a distinct module from the pre-ligule patterning genes (those genes outlined in Section 4.3.1) in gene network analyses [110]. Genes able to ectopically induce new blade/sheath boundaries include the homeobox genes KNOTTED1 (KN1), GNARLEY1 (KNOX4), LIGULELESS 3, LIGULELESS 4, and the TCP transcription factor WAVY AURICLES IN BLADE1 (Wab1) [2,107,119-126]. An additional ectopic blade/sheath boundary mutant, Hairy sheath frayed (Hsf), has also been identified. Hsf develops sheath-like prongs on the blade of the leaf $[127,128]$ and is involved in cytokinin (CK) signaling [Michael Muszynski, Personal Communication]. These mutants suggest that KNOXs, TCPs, and CK signaling could be involved in proximal patterning of the grass leaf before ligule and auricle outgrowth occurs.

In support of the hypothesis that KNOX genes are involved in this proximal/distal patterning, KNOX protein accumulates at the base of developing grass leaves, suggesting that KNOXs could provide a "proximal" patterning signal. KNOX expression in this boundary may provide competency to respond to the ligule and auricle patterning factors. Interestingly, the KNOX interacting factors, BEL12 and 14, are expressed in the developing ligule [101,129] and are bound and modulated by KN1 [44]. LG3, which is also expressed at the ligule, interacts with both BEL12 and 14 [Aromdee and Hake, unpublished data]. Ectopic expression of KNOX genes in other systems also triggers morphological changes and outgrowths. For example, ectopic expression of the KNOX gene BKN3 in the barley lemma/awn boundary triggers the formation of an ectopic floral meristem and triangular marginal outgrowths. This dramatic morphological change correlates with an induced re-orientation 
of tissue cell polarity (as shown by the localization of SoPIN1) and the ectopic expression of boundary genes such as NAM [31], lending further support to the hypothesis that KNOX genes are able to pattern new boundary regions and morphological changes.

$W A B 1$ is normally expressed in developing inflorescences and is required for branch initiation in the tassel [121]. In the dominant gain of function mutant, WAB1 is ectopically expressed in the leaf blade and induces the ectopic expression of $L G 1$, which leads to auricle-like outgrowths in the blade (Figure 3). Although WAB1 does not play a role in normal leaf development, it could indicate a possible role for other TCP transcription factors in the regulation of LG1 expression in the leaf.

The recessive mutant extended auricles 1 (eta1) develops ectopic auricle tissue, and has a diffuse blade/ sheath boundary. The causal mutation of eta1 has not been identified, but it has been shown to be involved in the same pathway as LG1 and LG2 [130,131]. ETA1 is proposed to be a possible component of the bridge between the blade/sheath boundary patterning network and the pre-ligule patterning network.

\subsubsection{A Proposed Model of Blade/Sheath Boundary Specification}

Given that liguleless mutants maintain a blade and a sheath, it is likely that the blade/sheath boundary specification can be separated into two distinct phases.

First, a broad domain boundary between the sheath and blade is specified early in the leaf primordium. Since there are no reported mutants which are only sheath, only blade, or a hybrid of the two identities, it is likely that this stage is genetically redundant. This phase involves factors such as KNOX genes, and genes associated with the sheath such as $B O P$, as well as phytohormone gradients such as auxin and cytokinin. Although KNOX gene expression is excluded from developing leaf primordia, the accumulation of KNOX protein in the base of the developing leaf could promote the expression of $B O P$ genes, specifying the sheath domain. This would predict that the loss of function of multiple $B O P$ genes with overlapping functions in the grasses would result in a loss of sheath identity, and that ectopic KNOX expression would induce BOP expression. Similarly, overexpression of a BOP gene in the developing grass leaf would increase the proportion of sheath to blade. Based on the RNAseq work by Johnston et al. and the mutant phenotypes of Hsf, converging gradients of auxin (distal signal) and cytokinin (proximal signal) could contribute to patterning the boundary between the sheath and blade. Early studies that added auxin transport inhibitors to maize seedlings showed a disruption of the blade sheath boundary [132]. It would be of great interest to explore the distribution of auxin and cytokinin in the developing leaf primordium using reporters, as well as to test the effects of differential hormone treatments on the ratio of sheath to blade.

The second phase of boundary development involves the refinement of the blade sheath boundary and the ultimate specification of the pre-ligule band at P6 (Figure 4). This phase likely involves genes expressed at the ligule and those that have liguleless phenotypes. Within this stage, we can predict factors involved in refining the boundary, and those important for ligule specification and outgrowth to function. The $\lg 2$ mutant has a diffuse boundary, which suggests that it is involved in refining the boundary region. $\lg 1$ has a distinct blade/sheath boundary, and is therefore likely specific to the specification and outgrowth of the ligule. The displacement of the ligule and the blade/sheath boundary in the Lgn mutant suggests that a phosphorylation cascade and BR signaling may be involved in propagation of the "ligule signal" out from the midrib to the margins of the leaf. It will be of great interest to look at the relative timing of ligule specific gene expression alongside PIN orientations to determine how the ligule region is defined. 


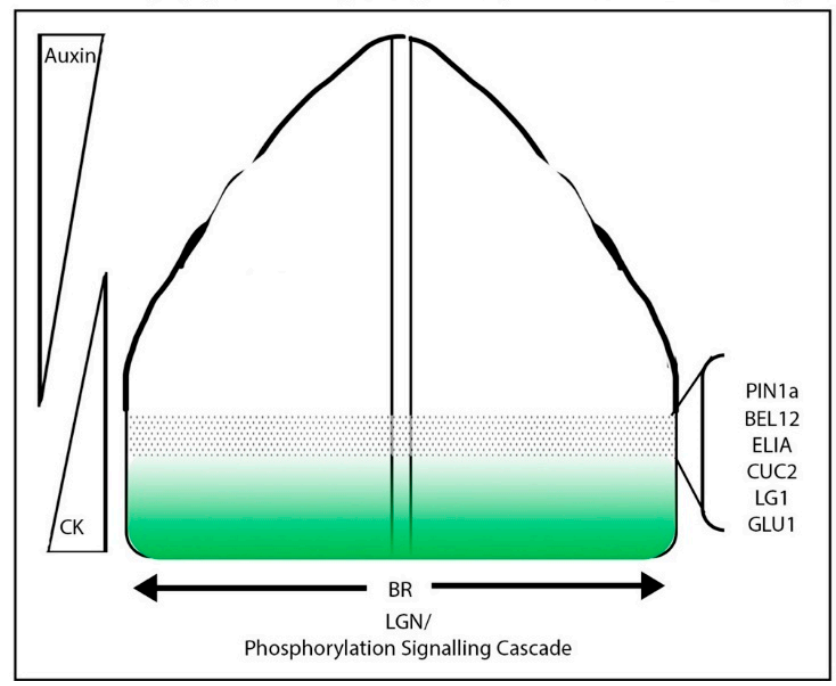

Figure 4. How is a ligule patterned? Summary of the known gene expression patterns in the developing grass leaf at $\mathrm{P} 6$ and the hypothetical gradients of phytohormone signaling. Green represents the expression pattern of the BOP homologues, which overlaps with $L G 3, B R D 1$, and BEL14 in the base of the leaf. The dotted region represents the pre-ligule band, where PIN1a, BEL12, ELIA, CUC2, LG1, and GLU1 are expressed. Hypothesized gradients are also illustrated for Auxin, CK, and BR.

\section{Pleiotropy and Boundaries}

Given the profound effects on morphology, manipulation of genes involved in boundary specification could lead to modulation of the leaf phenotype, providing a rich resource for phenotypic plasticity to be tested in different environmental and field conditions. For example, in dense planting fields, more upright leaves, especially in the upper canopy are important, whereas more sparse, inter-cropped fields, may benefit from a wider leaf angle. Many of the existing mutants, however, have pleiotropic effects, which can negatively impact yield. For example, both the maize $\lg 1$ and $\lg 2$ mutants have upright leaves, but also have severely reduced tassel branch numbers [102,133,134]. Similarly, the barley mutant eliA is pleiotropic with a shorter stature, ligule defects, and compact inflorescence spikes [118]. This pleiotropy is not unique to the grasses. For example, the $c u c 2, c u c 3$, and lof1/2 mutants in Arabidopsis all have defects in branching [16,135-137]. The combined effects on both leaf architecture, branching and inflorescence architecture of many of these mutants, often leads to a reduced yield.

To explore whether individual phenotypic components could modulate yield, the pleiotropy needs to be broken. Pleiotropic effects could be modulated through: (1) changes in cis-regulatory elements that influence the timing or spatial distribution of expression, (2) altering tissue specific partners, and (3) modulating different tissue-specific downstream elements. For example, DELLA mutants have pleiotropic defects, affecting both stem growth and meristem size. DELLA's effect on stem growth has been linked to direct regulation of the cell cycle inhibitor KRP2 and is independent of meristem size regulation. The genetic uncoupling of stem elongation and meristem size via modulation of KRP2 was effective in both Arabidopsis and barley, generating semi-dwarf plants [138].

In model eudicots like Arabidopsis, transgenics are used to overcome pleiotropic effects of key regulatory genes. The extensive transgenic toolkits in Arabidopsis enable cell-type specific and inducible expression systems [139] to modulate gene expression in a precise manner. For example, conditional dsRNAi silencing of CLV3 allowed identification of the specific function of CLV3 in the meristem, which uncoupled the effects from the severe global changes caused in the full clv3 mutant [140]. In transformation tractable species, the use of genome editing via CRISPR/cas9, for example, can also be used to alter cis-regulatory elements to uncouple phenotypes. This technique has already been used successfully in tomato to combine alleles that were selected during domestication and more recent 
breeding for distinct flower morphology and fruit retention traits. Combining the two traits highlighted a negative epistatic relationship, which could be overcome by varying the dosage of the relevant genes using homo/heterozygote mutants, and through CRISPR/cas9 to introduce allelic variation [141]. The use of genome editing to introduce allelic variation in cis-regulatory sequences can also lead to an increase in phenotypic variation [142], which could be used as a resource to break pleiotropy.

Transgenic approaches can be more difficult in grass crops due to the expense and time of transgenics, difficulty in transgenerational maintenance of the transgene, and public opinions regarding genetic modification. Alternatively, rich natural diversity in species such as maize, can be taken advantage of to break links in pleotropic defects.

\section{Conclusions}

A common underlying mechanism for boundary specification exists between eudicots and grasses, specifying meristem/organ and intra-whorl boundaries during vegetative development. In both eudicots and grass crops, this mechanism has been co-opted to specify within organ boundaries to generate morphological diversity. In both cases, however, there are species and family-specific elements that modulate the core boundary network and highlight the importance of studying boundary specification in both eudicot models and grass crops. The dynamic regulation of these boundary regulatory networks could yield rich phenotypic diversity in agronomically important traits such as leaf angle, making use of targeted natural variation or genome editing in key nodes of the network.

Author Contributions: A.E.R. wrote the manuscript and S.H. helped edit.

Funding: The work was supported by NSF/BIOBBSRC 1547062 and NSF ECA-PGRP 1733606.

Acknowledgments: The work was supported by NSF/BIOBBSRC 1547062 and NSF ECA-PGRP 1733606.

Conflicts of Interest: The authors declare no conflict of interest.

\section{References}

1. Jackson, D.; Veit, B.; Hake, S. Expression of maize KNOTTED1 related homeobox genes in the shoot apical meristem predicts patterns of morphogenesis in the vegetative shoot. Development 1994, 120, 405-413.

2. Smith, L.G.; Greene, B.; Veit, B.; Hake, S. A dominant mutation in the maize homeobox gene, Knotted-1, causes its ectopic expression in leaf cells with altered fates. Development 1992, 116, 21-30. [PubMed]

3. Long, J.A.; Moan, E.I.; Medford, J.I.; Barton, M.K. A member of the KNOTTED class of homeodomain proteins encoded by the STM gene of Arabidopsis. Nature 1996, 379, 66-69. [CrossRef] [PubMed]

4. Heisler, M.G.; Hamant, O.; Krupinski, P.; Uyttewaal, M.; Ohno, C.; Jönsson, H.; Traas, J.; Meyerowitz, E.M. Alignment between PIN1 polarity and microtubule orientation in the shoot apical meristem reveals a tight coupling between morphogenesis and auxin transport. PLoS Biol. 2010, 8, e1000516. [CrossRef] [PubMed]

5. Abley, K.; De Reuille, P.B.; Strutt, D.; Bangham, A.; Prusinkiewicz, P.; Marée, A.F.M.; Grieneisen, V.A.; Coen, E. An intracellular partitioning-based framework for tissue cell polarity in plants and animals. Development 2013, 140, 2061-2074. [CrossRef]

6. Bayer, E.M.; Smith, R.S.; Mandel, T.; Nakayama, N.; Sauer, M.; Prusinkiewicz, P.; Kuhlemeier, C. Integration of transport-based models for phyllotaxis and midvein formation. Genes Dev. 2009, 23, 373-384. [CrossRef]

7. Bhatia, N.; Bozorg, B.; Larsson, A.; Ohno, C.; Jönsson, H.; Heisler, M.G. Auxin acts through MONOPTEROS to regulate plant cell polarity and pattern phyllotaxis. Curr. Biol. 2016, 26, 3202-3208. [CrossRef]

8. Jönsson, H.; Heisler, M.G.; Shapiro, B.E.; Meyerowitz, E.M.; Mjolsness, E. An auxin-driven polarized transport model for phyllotaxis. Proc. Natl. Acad. Sci. USA 2006, 103, 1633-1638. [CrossRef]

9. Smith, R.S.; Guyomarc'h, S.; Mandel, T.; Reinhardt, D.; Kuhlemeier, C.; Prusinkiewicz, P. A plausible model of phyllotaxis. Proc. Natl. Acad. Sci. USA 2006, 103, 1301-1306. [CrossRef]

10. Stoma, S.; Lucas, M.; Chopard, J.; Schaedel, M.; Traas, J.; Godin, C. Flux-based transport enhancement as a plausible unifying mechanism for auxin transport in meristem development. PLoS Comput. Biol. 2008, 4, e1000207. [CrossRef] 
11. Benková, E.; Michniewicz, M.; Sauer, M.; Teichmann, T.; Seifertová, D.; Jürgens, G.; Friml, J. Local, efflux-dependent auxin gradients as a common module for plant organ formation. Cell 2003, 115, 591-602. [CrossRef]

12. Heisler, M.G.; Ohno, C.; Das, P.; Sieber, P.; Reddy, G.V.; Long, J.A.; Meyerowitz, E.M. Patterns of Auxin Transport and Gene Expression during Primordium Development Revealed by Live Imaging of the Arabidopsis Inflorescence Meristem. Curr. Biol. 2005, 15, 1899-1911. [CrossRef] [PubMed]

13. Reinhardt, D.; Mandel, T.; Kuhlemeier, C. Auxin Regulates the Initiation and Radial Position of Plant Lateral Organs. Plant Cell 2000, 12, 507-518. [CrossRef] [PubMed]

14. Reinhardt, D.; Pesce, E.-R.; Stieger, P.; Mandel, T.; Baltensperger, K.; Bennett, M.; Traas, J.; Friml, J.; Kuhlemeier, C. Regulation of phyllotaxis by polar auxin transport. Nature 2003, 426, 255. [CrossRef] [PubMed]

15. Okada, K.; Ueda, J.; Komaki, M.K.; Bell, C.J.; Shimura, Y. Requirement of the auxin polar transport system in early stages of Arabidopsis floral bud formation. Plant Cell 1991, 3, 677-684. [CrossRef] [PubMed]

16. Hibara, K.; Karim, M.R.; Takada, S.; Taoka, K.; Furutani, M.; Aida, M.; Tasaka, M. Arabidopsis CUP-SHAPED COTYLEDON3 Regulates Postembryonic Shoot Meristem and Organ Boundary Formation. Plant Cell 2006, 18, 2946-2957. [CrossRef] [PubMed]

17. Hamant, O.; Heisler, M.G.; Jönsson, H.; Krupinski, P.; Uyttewaal, M.; Bokov, P.; Corson, F.; Sahlin, P.; Boudaoud, A.; Meyerowitz, E.M. Developmental patterning by mechanical signals in Arabidopsis. Science 2008, 322, 1650-1655. [CrossRef] [PubMed]

18. Abad, U.; Sassi, M.; Traas, J. Flower development: From morphodynamics to morphomechanics. Philos. Trans. R. Soc. Lond. B. Biol. Sci. 2017, 372. [CrossRef] [PubMed]

19. Green, P.B. Mechanism for Plant Cellular Morphogenesis. Science 1962, 138, 1404-1405. [CrossRef]

20. Hamant, O.; Traas, J. The mechanics behind plant development. New Phytol. 2010, 185, 369-385. [CrossRef]

21. Coen, E.; Rebocho, A.B. Resolving conflicts: Modeling genetic control of plant morphogenesis. Dev. Cell 2016, 38, 579-583. [CrossRef] [PubMed]

22. Rebocho, A.B.; Kennaway, J.R.; Bangham, J.A.; Coen, E. Formation and Shaping of the Antirrhinum Flower through Modulation of the CUP Boundary Gene. Curr. Biol. 2017, 27, 2610-2622. [CrossRef] [PubMed]

23. Juarez, M.T.; Twigg, R.W.; Timmermans, M.C.P. Specification of adaxial cell fate during maize leaf development. Development 2004, 131, 4533-4544. [CrossRef] [PubMed]

24. McConnell, J.R.; Emery, J.; Eshed, Y.; Bao, N.; Bowman, J.; Barton, M.K. Role of PHABULOSA and PHAVOLUTA in determining radial patterning in shoots. Nature 2001, 411, 709. [CrossRef] [PubMed]

25. Waites, R.; Hudson, A. Phantastica: A gene required for dorsoventrality of leaves in Antirrhinum majus. Development 1995, 121, 2143-2154.

26. Kumar, S.; Mishra, R.K.; Kumar, A.; Srivastava, S.; Chaudhary, S. Regulation of stipule development by COCHLEATA and STIPULE-REDUCED genes in pea Pisum sativum. Planta 2009, 230, 449-458. [CrossRef] [PubMed]

27. Harlan, H.V. The origin of hooded barley. J. Hered. 1931, 22, 265-272. [CrossRef]

28. Müller, K.J.; Romano, N.; Gerstner, O.; Garcia-Marotot, F.; Pozzi, C.; Salamini, F.; Rohde, W. The barley Hooded mutation caused by a duplication in a homeobox gene intron. Nature 1995, 374, 727. [CrossRef]

29. Stebbins, G.L.; Yagil, E. The morphogenetic effects of the hooded gene in barley I: The course of development in hooded and awned genotypes. Genetics 1966, 54, 727.

30. Williams-Carrier, R.E.; Lie, Y.S.; Hake, S.; Lemaux, P.G. Ectopic expression of the maize kn1 gene phenocopies the Hooded mutant of barley. Development 1997, 124, 3737-3745.

31. Richardson, A.E.; Rebocho, A.B.; Coen, E.S. Ectopic KNOX expression affects plant development by altering tissue cell polarity and identity. Plant Cell 2016. [CrossRef]

32. Chuck, G.; Lincoln, C.; Hake, S. KNAT1 induces lobed leaves with ectopic meristems when overexpressed in Arabidopsis. Plant Cell 1996, 8, 1277-1289. [CrossRef] [PubMed]

33. Shuai, B.; Reynaga-Peña, C.G.; Springer, P.S. The Lateral Organ Boundaries Gene Defines a Novel, Plant-Specific Gene Family. Plant Physiol. 2002, 129, 747-761. [CrossRef] [PubMed]

34. Lee, B.H.; Jeon, J.O.; Lee, M.M.; Kim, J.H. Genetic interaction between GROWTH-REGULATING FACTOR and CUP-SHAPED COTYLEDON in organ separation. Plant Signal. Behav. 2015, 10, e988071. [CrossRef] [PubMed] 
35. Bell, E.M.; Lin, W.; Husbands, A.Y.; Yu, L.; Jaganatha, V.; Jablonska, B.; Mangeon, A.; Neff, M.M.; Girke, T.; Springer, P.S. Arabidopsis LATERAL ORGAN BOUNDARIES negatively regulates brassinosteroid accumulation to limit growth in organ boundaries. Proc. Natl. Acad. Sci. USA 2012, 109, 21146-21151. [CrossRef] [PubMed]

36. Vroemen, C.W.; Mordhorst, A.P.; Albrecht, C.; Kwaaitaal, M.A.C.J.; de Vries, S.C. The CUP-SHAPED COTYLEDON3 gene is required for boundary and shoot meristem formation in Arabidopsis. Plant Cell 2003, 15, 1563-1577. [CrossRef]

37. Takeda, S.; Hanano, K.; Kariya, A.; Shimizu, S.; Zhao, L.; Matsui, M.; Tasaka, M.; Aida, M. CUP-SHAPED COTYLEDON1 transcription factor activates the expression of LSH4 and LSH3, two members of the ALOG gene family, in shoot organ boundary cells. Plant J. 2011, 66, 1066-1077. [CrossRef]

38. Tian, C.; Zhang, X.; He, J.; Yu, H.; Wang, Y.; Shi, B.; Han, Y.; Wang, G.; Feng, X.; Zhang, C.; et al. An organ boundary-enriched gene regulatory network uncovers regulatory hierarchies underlying axillary meristem initiation. Mol. Syst. Biol. 2014, 10, 755. [CrossRef]

39. Borghi, L.; Bureau, M.; Simon, R. Arabidopsis JAGGED LATERAL ORGANS is Expressed in Boundaries and Coordinates KNOX and PIN Activity. Plant Cell 2007, 19, 1795-1808. [CrossRef]

40. Spinelli, S.V.; Martin, A.P.; Viola, I.L.; Gonzalez, D.H.; Palatnik, J.F. A mechanistic link between STM and CUC1 during Arabidopsis development. Plant Physiol. 2011. [CrossRef]

41. Ha, C.M.; Jun, J.H.; Fletcher, J.C. Control of Arabidopsis Leaf Morphogenesis Through Regulation of the YABBY and KNOX Families of Transcription Factors. Genetics 2010, 186, 197-206. [CrossRef] [PubMed]

42. Ichihashi, Y.; Aguilar-Martínez, J.A.; Farhi, M.; Chitwood, D.H.; Kumar, R.; Millon, L.V.; Peng, J.; Maloof, J.N.; Sinha, N.R. Evolutionary developmental transcriptomics reveals a gene network module regulating interspecific diversity in plant leaf shape. Proc. Natl. Acad. Sci. USA 2014. [CrossRef]

43. Norberg, M.; Holmlund, M.; Nilsson, O. The BLADE ON PETIOLE genes act redundantly to control the growth and development of lateral organs. Development 2005, 132, 2203-2213. [CrossRef] [PubMed]

44. Bolduc, N.; Yilmaz, A.; Mejia-Guerra, M.K.; Morohashi, K.; O'connor, D.; Grotewold, E.; Hake, S. Unraveling the KNOTTED1 regulatory network in maize meristems. Genes Dev. 2012, 26, 1685-1690. [CrossRef] [PubMed]

45. Žádníková, P.; Simon, R. How boundaries control plant development. Curr. Opin. Plant Biol. 2014, 17, 116-125. [CrossRef] [PubMed]

46. Scofield, S.; Murison, A.; Jones, A.; Fozard, J.; Aida, M.; Band, L.R.; Bennett, M.; Murray, J.A.H. Coordination of meristem and boundary functions by transcription factors in the SHOOT MERISTEMLESS regulatory network. Development 2018. [CrossRef] [PubMed]

47. Clouse, S.D.; Langford, M.; McMorris, T.C. A Brassinosteroid-Insensitive Mutant in Arabidopsis thaliana Exhibits Multiple Defects in Growth and Development. Plant Physiol. 1996, 111, 671-678. [CrossRef] [PubMed]

48. Ha, C.M.; Jun, J.H.; Nam, H.G.; Fletcher, J.C. BLADE-ON-PETIOLE1 and 2 Control Arabidopsis Lateral Organ Fate through Regulation of LOB Domain and Adaxial-Abaxial Polarity Genes. Plant Cell 2007, 19, 1809-1825. [CrossRef]

49. Hepworth, S.R.; Zhang, Y.; McKim, S.; Li, X.; Haughn, G.W. BLADE-ON-PETIOLE-dependent signaling controls leaf and floral patterning in Arabidopsis. Plant Cell 2005, 17, 1434-1448. [CrossRef]

50. Bar, M.; Ori, N. Compound leaf development in model plant species. Curr. Opin. Plant Biol. 2015, 23, 61-69. [CrossRef]

51. Blein, T.; Pulido, A.; Vialette-Guiraud, A.; Nikovics, K.; Morin, H.; Hay, A.; Johansen, I.E.; Tsiantis, M.; Laufs, P. A Conserved Molecular Framework for Compound Leaf Development. Science 2008, 322, 1835-1839. [CrossRef] [PubMed]

52. Barkoulas, M.; Hay, A.; Kougioumoutzi, E.; Tsiantis, M. A developmental framework for dissected leaf formation in the Arabidopsis relative Cardamine hirsuta. Nat. Genet. 2008, 40, 1136. [CrossRef] [PubMed]

53. Hay, A.; Tsiantis, M. The genetic basis for differences in leaf form between Arabidopsis thaliana and its wild relative Cardamine hirsuta. Nat. Genet. 2006, 38, 942. [CrossRef] [PubMed]

54. Bilsborough, G.D.; Runions, A.; Barkoulas, M.; Jenkins, H.W.; Hasson, A.; Galinha, C.; Laufs, P.; Hay, A.; Prusinkiewicz, P.; Tsiantis, M. Model for the regulation of Arabidopsis thaliana leaf margin development. Proc. Natl. Acad. Sci. USA 2011, 108, 3424-3429. [CrossRef] [PubMed]

55. Nikovics, K.; Blein, T.; Peaucelle, A.; Ishida, T.; Morin, H.; Aida, M.; Laufs, P. The balance between the MIR164A and CUC2 genes controls leaf margin serration in Arabidopsis. Plant Cell 2006, 18, 2929-2945. [CrossRef] [PubMed] 
56. Hareven, D.; Gutfinger, T.; Parnis, A.; Eshed, Y.; Lifschitz, E. The Making of a Compound Leaf: Genetic Manipulation of Leaf Architecture in Tomato. Cell 1996, 84, 735-744. [CrossRef]

57. Gourlay, C.W.; Hofer, J.M.I.; Ellis, T.H.N. Pea Compound Leaf Architecture Is Regulated by Interactions among the Genes UNIFOLIATA, COCHLEATA, AFIL, and TENDRIL-LESS. Plant Cell 2000, 12, 1279-1294. [CrossRef] [PubMed]

58. Vlad, D.; Kierzkowski, D.; Rast, M.I.; Vuolo, F.; Ioio, R.D.; Galinha, C.; Gan, X.; Hajheidari, M.; Hay, A.; Smith, R.S. Leaf shape evolution through duplication, regulatory diversification, and loss of a homeobox gene. Science 2014, 343, 780-783. [CrossRef]

59. Chaw, S.-M.; Chang, C.-C.; Chen, H.-L.; Li, W.-H. Dating the monocot-dicot divergence and the origin of core eudicots using whole chloroplast genomes. J. Mol. Evol. 2004, 58, 424-441.

60. Sharman, B.C. Developmental anatomy of the shoot of Zea mays L. Ann. Bot. 1942, 6, 245-282. [CrossRef]

61. Poethig, R.S.; Szymkowiak, E.J. Clonal analysis of leaf development in maize. Available online: http: / / agris.fao.org/agris-search/search.do?recordID=IT9561182 (accessed on 24 December 2018).

62. Scanlon, M.J. The Polar Auxin Transport Inhibitor N-1-Naphthylphthalamic Acid Disrupts Leaf Initiation, KNOX Protein Regulation, and Formation of Leaf Margins in Maize. Plant Physiol. 2003, 133, 597-605. [CrossRef] [PubMed]

63. O'Connor, D.L.; Elton, S.; Ticchiarelli, F.; Hsia, M.M.; Vogel, J.P.; Leyser, O. Cross-species functional diversity within the PIN auxin efflux protein family. Elife 2017, 6, e31804. [CrossRef] [PubMed]

64. O'Connor, D.L.; Runions, A.; Sluis, A.; Bragg, J.; Vogel, J.P.; Prusinkiewicz, P.; Hake, S. A Division in PIN-Mediated Auxin Patterning during Organ Initiation in Grasses. PLOS Comput. Biol. 2014, 10, e1003447. [CrossRef] [PubMed]

65. Martinez, C.C.; Koenig, D.; Chitwood, D.H.; Sinha, N.R. A sister of PIN1 gene in tomato (Solanum lycopersicum) defines leaf and flower organ initiation patterns by maintaining epidermal auxin flux. Dev. Biol. 2016, 419, 85-98. [CrossRef] [PubMed]

66. Zhou, C.; Han, L.; Wang, Z.-Y. Potential but limited redundant roles of MtPIN4, MtPIN5 and MtPIN10/SLM1 in the development of Medicago truncatula. Plant Signal. Behav. 2011, 6, 1834-1836. [CrossRef] [PubMed]

67. Pepper, G.E.; Pearce, R.B.; Mock, J.J. Leaf Orientation and Yield of Maize1. Crop Sci. 1977, 17, 883-886. [CrossRef]

68. Araus, J.L.; Reynolds, M.P.; Acevedo, E. Leaf Posture, Grain Yield, Growth, Leaf Structure, and Carbon Isotope Discrimination in Wheat. Crop Sci. 1993, 33, 1273-1279. [CrossRef]

69. Nan, S.S.; Ootsuki, Y.; Adachi, S.; Yamamoto, T.; Ueda, T.; Tanabata, T.; Motobayashi, T.; Ookawa, T.; Hirasawa, T. A near-isogenic rice line carrying a QTL for larger leaf inclination angle yields heavier biomass and grain. Field Crop. Res. 2018, 219, 131-138. [CrossRef]

70. Pendleton, J.W.; Smith, G.E.; Winter, S.R.; Johnston, T.J. Field Investigations of the Relationships of Leaf (Angle in Corn (Zea mays L.) to Grain Yield and Apparent Photosynthesis1. Agron. J. 1968, 60, 422-424. [CrossRef]

71. Duvick, D.N. The contribution of breeding to yield advances in maize (Zea mays L.). Adv. Agron. 2005, 86, 83-145.

72. Mantilla-Perez, M.B.; Salas Fernandez, M.G. Differential manipulation of leaf angle throughout the canopy: Current status and prospects. J. Exp. Bot. 2017, 68, 5699-5717. [CrossRef] [PubMed]

73. Lambert, R.J.; Johnson, R.R. Leaf Angle, Tassel Morphology, and the Performance of Maize Hybrids 1. Crop Sci. 1978, 18, 499-502. [CrossRef]

74. Duncan, W.G. Leaf Angles, Leaf Area, and Canopy Photosynthesis 1. Crop Sci. 1971, 11, 482-485. [CrossRef]

75. Tian, F.; Bradbury, P.J.; Brown, P.J.; Hung, H.; Sun, Q.; Flint-Garcia, S.; Rocheford, T.R.; McMullen, M.D.; Holland, J.B.; Buckler, E.S. Genome-wide association study of leaf architecture in the maize nested association mapping population. Nat. Genet. 2011, 43, 159. [CrossRef] [PubMed]

76. Hernandez, M.L.; Passas, H.J.; Smith, L.G. Clonal Analysis of Epidermal Patterning during Maize Leaf Development. Dev. Biol. 1999, 216, 646-658. [CrossRef] [PubMed]

77. Sylvester, A.W.; Cande, W.Z.; Freeling, M. Division and differentiation during normal and liguleless-1 maize leaf development. Development 1990, 110, 985-1000. [PubMed]

78. Weir, I.; Lu, J.; Cook, H.; Causier, B.; Schwarz-Sommer, Z.; Davies, B. CUPULIFORMIS establishes lateral organ boundaries in Antirrhinum. Development 2004, 131, 915-922. [CrossRef] [PubMed] 
79. Souer, E.; van Houwelingen, A.; Kloos, D.; Mol, J.; Koes, R. The no apical meristem gene of Petunia is required for pattern formation in embryos and flowers and is expressed at meristem and primordia boundaries. Cell 1996, 85, 159-170. [CrossRef]

80. Ha, C.M.; Kim, G.-T.; Kim, B.C.; Jun, J.H.; Soh, M.S.; Ueno, Y.; Machida, Y.; Tsukaya, H.; Nam, H.G. The BLADE-ON-PETIOLE 1 gene controls leaf pattern formation through the modulation of meristematic activity in Arabidopsis. Development 2003, 130, 161-172. [CrossRef]

81. Zimmermann, R.; Werr, W. Pattern Formation in the Monocot Embryo as Revealed by NAM and CUC3 Orthologues from Zea mays L. Plant Mol. Biol. 2005, 58, 669-685. [CrossRef]

82. Adam, H.; Marguerettaz, M.; Qadri, R.; Adroher, B.; Richaud, F.; Collin, M.; Thuillet, A.-C.; Vigouroux, Y.; Laufs, P.; Tregear, J.W.; et al. Divergent Expression Patterns of miR164 and CUP-SHAPED COTYLEDON Genes in Palms and Other Monocots: Implication for the Evolution of Meristem Function in Angiosperms. Mol. Biol. Evol. 2011, 28, 1439-1454. [CrossRef] [PubMed]

83. Vialette-Guiraud, A.C.M.; Adam, H.; Finet, C.; Jasinski, S.; Jouannic, S.; Scutt, C.P. Insights from ANA-grade angiosperms into the early evolution of CUP-SHAPED COTYLEDON genes. Ann. Bot. 2011, 107, 1511-1519. [CrossRef] [PubMed]

84. Dong, Z.; Li, W.; Unger-Wallace, E.; Yang, J.; Vollbrecht, E.; Chuck, G. Ideal crop plant architecture is mediated by tassels replace upper ears1, a BTB/POZ ankyrin repeat gene directly targeted by TEOSINTE BRANCHED1. Proc. Natl. Acad. Sci. USA 2017, 114, E8656-E8664. [CrossRef] [PubMed]

85. Sunkar, R.; Zhou, X.; Zheng, Y.; Zhang, W.; Zhu, J.-K. Identification of novel and candidate miRNAs in rice by high throughput sequencing. BMC Plant Biol. 2008, 8, 25. [CrossRef] [PubMed]

86. Sieber, P.; Wellmer, F.; Gheyselinck, J.; Riechmann, J.L.; Meyerowitz, E.M. Redundancy and specialization among plant microRNAs: Role of the MIR164 family in developmental robustness. Development 2007, 134, 1051-1060. [CrossRef]

87. Li, J.; Guo, G.; Guo, W.; Guo, G.; Tong, D.; Ni, Z.; Sun, Q.; Yao, Y. miRNA164-directed cleavage of ZmNAC1 confers lateral root development in maize (Zea mays L.). BMC Plant Biol. 2012, 12, 220. [CrossRef]

88. Xiong, Y.; Liu, T.; Tian, C.; Sun, S.; Li, J.; Chen, M. Transcription Factors in Rice: A Genome-wide Comparative Analysis between Monocots and Eudicots. Plant Mol. Biol. 2005, 59, 191-203. [CrossRef]

89. Tsuda, K.; Akiba, T.; Kimura, F.; Ishibashi, M.; Moriya, C.; Nakagawa, K.; Kurata, N.; Ito, Y. ONION2 fatty acid elongase is required for shoot development in rice. Plant Cell Physiol. 2013, 54, 209-217. [CrossRef]

90. Tsuda, K.; Ito, Y.; Yamaki, S.; Miyao, A.; Hirochika, H.; Kurata, N. Isolation and mapping of three rice mutants that showed ectopic expression of KNOX genes in leaves. Plant Sci. 2009, 177, 131-135. [CrossRef]

91. Takasugi, T.; Ito, Y. Altered expression of auxin-related genes in the fatty acid elongase mutant oni1 of rice. Plant Signal Behav. 2011, 6. [CrossRef]

92. Akiba, T.; Hibara, K.I.; Kimura, F.; Tsuda, K.; Shibata, K.; Ishibashi, M.; Moriya, C.; Nakagawa, K.; Kurata, N.; Itoh, J.I.; et al. Organ fusion and defective shoot development in oni3 mutants of rice. Plant Cell Physiol. 2014, 55, 42-51. [CrossRef] [PubMed]

93. Sinha, N.; Lynch, M. Fused organs in the adherent1 mutation in maize show altered epidermal walls with no perturbations in tissue identities. Planta 1998, 206, 184-195. [CrossRef]

94. La Rocca, N.; Manzotti, P.S.; Cavaiuolo, M.; Barbante, A.; Dalla Vecchia, F.; Gabotti, D.; Gendrot, G.; Horner, D.S.; Krstajic, J.; Persico, M.; et al. The maize fused leaves1 (fdl1) gene controls organ separation in the embryo and seedling shoot and promotes coleoptile opening. J. Exp. Bot. 2015, 66, 5753-5767. [CrossRef] [PubMed]

95. Tavakol, E.; Okagaki, R.; Verderio, G.; Shariati, V.; Hussien, A.; Bilgic, H.; Scanlon, M.J.; Todt, N.R.; Close, T.J.; Druka, A. The barley Uniculme4 gene encodes a BLADE-ON-PETIOLE-like protein that controls tillering and leaf patterning. Plant Physiol. 2015, 168, 164-174. [CrossRef] [PubMed]

96. Mangeon, A.; Lin, W.; Springer, P.S. Functional divergence in the Arabidopsis LOB-domain gene family. Plant Signal. Behav. 2012, 7, 1544-1547. [CrossRef] [PubMed]

97. Bortiri, E.; Chuck, G.; Vollbrecht, E.; Rocheford, T.; Martienssen, R.; Hake, S. Ramosa2 Encodes a LATERAL ORGAN BOUNDARY Domain Protein That Determines the Fate of Stem Cells in Branch Meristems of Maize. Plant Cell 2006, 18, 574-585. [CrossRef] [PubMed]

98. Johnston, R.; Leiboff, S.; Scanlon, M.J. Ontogeny of the sheathing leaf base in maize (Zea mays). New Phytol. 2014, 306-315. [CrossRef] 
99. Scanlon, M.J.; Chen, K.D.; McKnight, C.C. The narrow sheath Duplicate Genes: Sectors of Dual Aneuploidy Reveal Ancestrally Conserved Gene Functions During Maize Leaf Development. Genetics 2000, 155, 1379-1389.

100. Moon, J.; Candela, H.; Hake, S. The Liguleless narrow mutation affects proximal-distal signaling and leaf growth. Development 2013, 140, 405-412. [CrossRef]

101. Johnston, R.; Wang, M.; Sun, Q.; Sylvester, A.W.; Hake, S.; Scanlon, M.J. Transcriptomic Analyses Indicate That Maize Ligule Development Recapitulates Gene Expression Patterns That Occur during Lateral Organ Initiation. Plant Cell Online 2014. [CrossRef]

102. Moreno, M.A.; Harper, L.C.; Krueger, R.W.; Dellaporta, S.L.; Freeling, M. liguleless1 encodes a nuclear-localized protein required for induction of ligules and auricles during maize leaf organogenesis. Genes Dev. 1997, 11, 616-628. [CrossRef] [PubMed]

103. Lee, J.; Park, J.J.; Kim, S.L.; Yim, J.; An, G. Mutations in the rice liguleless gene result in a complete loss of the auricle, ligule, and laminar joint. Plant Mol. Biol. 2007, 65, 487-499. [CrossRef] [PubMed]

104. Rossini, L.; Vecchietti, A.; Nicoloso, L.; Stein, N.; Franzago, S.; Salamini, F.; Pozzi, C. Candidate genes for barley mutants involved in plant architecture: An in silico approach. Theor. Appl. Genet. 2006, 112, 1073-1085. [CrossRef] [PubMed]

105. Harper, L.; Freeling, M. Interactions of liguleless1 and liguleless2 function during ligule induction in maize. Genetics 1996, 144, 1871-1882. [PubMed]

106. Walsh, J.; Waters, C.A.; Freeling, M. The maize gene liguleless2 encodes a basic leucine zipper protein involved in the establishment of the leaf blade-sheath boundary. Genes Dev. 1998, 12, 208-218. [CrossRef] [PubMed]

107. Hay, A.; Hake, S. The dominant mutant Wavy auricle in blade1 disrupts patterning in a lateral domain of the maize leaf. Plant Physiol. 2004, 135, 300-308. [CrossRef] [PubMed]

108. Jakoby, M.; Weisshaar, B.; Droge-Laser, W.; Vicente-Carbajosa, J.; Tiedemann, J.; Kroj, T.; Parcy, F. bZIP transcription factors in Arabidopsis. Trends Plant Sci. 2002, 7, 106-111. [CrossRef]

109. Schütze, K.; Harter, K.; Chaban, C. Post-translational regulation of plant bZIP factors. Trends Plant Sci. 2008, 13, 247-255. [CrossRef] [PubMed]

110. Ma, S.; Ding, Z.; Li, P. Maize network analysis revealed gene modules involved in development, nutrients utilization, metabolism, and stress response. BMC Plant Biol. 2017, 17, 131. [CrossRef] [PubMed]

111. Sakamoto, T.; Morinaka, Y.; Ohnishi, T.; Sunohara, H.; Fujioka, S.; Ueguchi-Tanaka, M.; Mizutani, M.; Sakata, K.; Takatsuto, S.; Yoshida, S. Erect leaves caused by brassinosteroid deficiency increase biomass production and grain yield in rice. Nat. Biotechnol. 2006, 24, 105. [CrossRef]

112. Hong, Z.; Ueguchi-Tanaka, M.; Umemura, K.; Uozu, S.; Fujioka, S.; Takatsuto, S.; Yoshida, S.; Ashikari, M.; Kitano, H.; Matsuoka, M. A rice brassinosteroid-deficient mutant, ebisu dwarf (d2), is caused by a loss of function of a new member of cytochrome P450. Plant Cell 2003, 15, 2900-2910. [CrossRef] [PubMed]

113. Hong, Z.; Ueguchi-Tanaka, M.; Shimizu-Sato, S.; Inukai, Y.; Fujioka, S.; Shimada, Y.; Takatsuto, S.; Agetsuma, M.; Yoshida, S.; Watanabe, Y. Loss-of-function of a rice brassinosteroid biosynthetic enzyme, C-6 oxidase, prevents the organized arrangement and polar elongation of cells in the leaves and stem. Plant J. 2002, 32, 495-508. [CrossRef] [PubMed]

114. Yamamuro, C.; Ihara, Y.; Wu, X.; Noguchi, T.; Fujioka, S.; Takatsuto, S.; Ashikari, M.; Kitano, H.; Matsuoka, M. Loss of function of a rice brassinosteroid insensitive1 homolog prevents internode elongation and bending of the lamina joint. Plant Cell 2000, 12, 1591-1605. [CrossRef] [PubMed]

115. Kir, G.; Ye, H.; Nelissen, H.; Neelakandan, A.K.; Kusnandar, A.S.; Luo, A.; Inzé, D.; Sylvester, A.W.; Yin, Y.; Becraft, P.W. RNA interference knockdown of BRASSINOSTEROID INSENSITIVE1 in maize reveals novel functions for brassinosteroid signaling in controlling plant architecture. Plant Physiol. 2015, 169, 826-839. [CrossRef] [PubMed]

116. Li, D.; Wang, L.; Wang, M.; Xu, Y.; Luo, W.; Liu, Y.; Xu, Z.; Li, J.; Chong, K. Engineering OsBAK1 gene as a molecular tool to improve rice architecture for high yield. Plant Biotechnol. J. 2009, 7, 791-806. [CrossRef]

117. Makarevitch, I.; Thompson, A.; Muehlbauer, G.J.; Springer, N.M. Brd1 Gene in Maize Encodes a Brassinosteroid C-6 Oxidase. PLoS ONE 2012, 7, e30798. [CrossRef]

118. Okagaki, R.J.; Haaning, A.; Bilgic, H.; Heinen, S.; Druka, A.; Bayer, M.; Waugh, R.; Muehlbauer, G.J. ELIGULUM-A regulates lateral branch and leaf development in barley. Plant Physiol. 2018. [CrossRef]

119. Vollbrecht, E.; Veit, B.; Sinha, N.; Hake, S. The developmental gene Knotted-1 is a member of a maize homeobox gene family. Nature 1991, 350, 241. [CrossRef] 
120. Ramirez, J.; Bolduc, N.; Lisch, D.; Hake, S. Distal expression of knotted1 in maize leaves leads to reestablishment of proximal/distal patterning and leaf dissection. Plant Physiol. 2009, 151, 1878-1888. [CrossRef]

121. Lewis, M.W.; Bolduc, N.; Hake, K.; Htike, Y.; Hay, A.; Candela, H.; Hake, S. Gene regulatory interactions at lateral organ boundaries in maize. Development 2014, 141, 4590-4597. [CrossRef]

122. Foster, T.; Yamaguchi, J.; Wong, B.C.; Veit, B.; Hake, S. Gnarley1 is a dominant mutation in the knox4 homeobox gene affecting cell shape and identity. Plant Cell 1999, 11, 1239-1252. [CrossRef] [PubMed]

123. Foster, T.; Veit, B.; Hake, S. Mosaic analysis of the dominant mutant, Gnarley1-R, reveals distinct lateral and transverse signaling pathways during maize leaf development. Development 1999, 126, 305-313. [PubMed]

124. Muehlbauer, G.J.; Fowler, J.E.; Girard, L.; Tyers, R.; Harper, L.; Freeling, M. Ectopic Expression of the Maize Homeobox Gene Liguleless3 Alters Cell Fates in the Leaf 1. Plant Physiol. 1999, 119, 651-662. [CrossRef] [PubMed]

125. Fowler, J.E.; Muehlbauer, G.J.; Freeling, M. Mosaic analysis of the liguleless3 mutant phenotype in maize by coordinate suppression of mutator-insertion alleles. Genetics 1996, 143, 489-503. [PubMed]

126. Muehlbauer, G.J.; Fowler, J.E.; Freeling, M. Sectors expressing the homeobox gene liguleless3 implicate a time-dependent mechanism for cell fate acquisition along the proximal-distal axis of the maize leaf. Development 1997, 124, 5097-5106. [PubMed]

127. Bertrand-Garcia, R.; Freeling, M. Hairy-Sheath Frayed \# 1-0: A Systemic, Heterochronic Mutant of Maize that Specifies Slow Developmental Stage Transitions. Am. J. Bot. 1991, 78, 747-765. [CrossRef]

128. Saberman, J.; Bertrand-Garcia, R. Hairy-sheath-frayed 1-O is a Non-Cell-Autonomous Mutation That Regulates Developmental Stage Transitions in Maize. J. Hered. 1997, 88, 549-553. [CrossRef]

129. Tsuda, K.; Abraham-Juarez, M.J.; Maeno, A.; Dong, Z.; Aromdee, D.; Meeley, R.; Shiroishi, T.; Nonomura, K.; Hake, S. KNOTTED1 cofactors, BLH12 and BLH14, regulate internode patterning and vein anastomosis in maize. Plant Cell 2017. [CrossRef]

130. Osmont, K.S.; Sadeghian, N.; Freeling, M. Mosaic analysis of extended auricle1 (eta1) suggests that a two-way signaling pathway is involved in positioning the blade/sheath boundary in Zea mays. Dev. Biol. 2006, 295, 1-12. [CrossRef]

131. Osmont, K.S.; Jesaitis, L.A.; Freeling, M. The extended auricle1 (eta1) Gene Is Essential for the Genetic Network Controlling Postinitiation Maize Leaf Development. Genetics 2003, 165, 1507-1519.

132. Tsiantis, M.; Brown, M.I.N.; Skibinski, G.; Langdale, J.A. Disruption of Auxin Transport Is Associated with Aberrant Leaf Development in Maize. Plant Physiol. 1999, 121, 1163-1168. [CrossRef] [PubMed]

133. Lewis, M.W.; Bolduc, N.; Hake, K.; Htike, Y.; Hay, A.; Candela, H. Recruitment of regulatory interactions from the inflorescence to the leaf in the dominant Wavy auricle in blade mutant. Development 2014, 141, 4590-4597. [CrossRef] [PubMed]

134. Walsh, J.; Freeling, M. The liguleless2 gene of maize functions during the transition from the vegetative to the reproductive shoot apex. Plant J. 1999, 19, 489-495. [CrossRef] [PubMed]

135. Busch, B.L.; Schmitz, G.; Rossmann, S.; Piron, F.; Ding, J.; Bendahmane, A.; Theres, K. Shoot branching and leaf dissection in tomato are regulated by homologous gene modules. Plant Cell 2011. [CrossRef] [PubMed]

136. Raman, S.; Greb, T.; Peaucelle, A.; Blein, T.; Laufs, P.; Theres, K. Interplay of miR164, CUP-SHAPED COTYLEDON genes and LATERAL SUPPRESSOR controls axillary meristem formation in Arabidopsis thaliana. Plant J. 2008, 55, 65-76. [CrossRef] [PubMed]

137. Lee, D.-K.; Geisler, M.; Springer, P.S. LATERAL ORGAN FUSION1 and LATERAL ORGAN FUSION2 function in lateral organ separation and axillary meristem formation in Arabidopsis. Development 2009, 136, 2423-2432. [CrossRef] [PubMed]

138. Serrano-Mislata, A.; Bencivenga, S.; Bush, M.; Schiessl, K.; Boden, S.; Sablowski, R. DELLA genes restrict inflorescence meristem function independently of plant height. Nat. Plants 2017, 3, 749-754. [CrossRef] [PubMed]

139. Schürholz, A.-K.; López-Salmerón, V.; Li, Z.; Forner, J.; Wenzl, C.; Gaillochet, C.; Augustin, S.; Barro, A.V.; Fuchs, M.; Gebert, M.; et al. A Comprehensive Toolkit for Inducible, Cell Type-Specific Gene Expression in Arabidopsis. Plant Physiol. 2018, 178, 40-53. [CrossRef] [PubMed]

140. Reddy, G.V.; Heisler, M.G.; Ehrhardt, D.W.; Meyerowitz, E.M. Real-time lineage analysis reveals oriented cell divisions associated with morphogenesis at the shoot apex of Arabidopsis thaliana. Development 2004, 131, 4225-4237. [CrossRef] [PubMed] 
141. Soyk, S.; Lemmon, Z.H.; Oved, M.; Fisher, J.; Liberatore, K.L.; Park, S.J.; Goren, A.; Jiang, K.; Ramos, A.; van der Knaap, E.; et al. Bypassing Negative Epistasis on Yield in Tomato Imposed by a Domestication Gene. Cell 2017, 169, 1142-1155. [CrossRef]

142. Rodríguez-Leal, D.; Lemmon, Z.H.; Man, J.; Bartlett, M.E.; Lippman, Z.B. Engineering Quantitative Trait Variation for Crop Improvement by Genome Editing. Cell 2017, 171, 470-480. [CrossRef] [PubMed] 